\title{
EFFECT OF COVID-19 HEALTH CARE PROVISION ON ANXIETY LEVEL AMONG NURSES IN HOSPITAL: META-ANALYSIS
}

\author{
Andang Sudarmono \\ Masters Program in Public Health, Universitas Sebelas Maret
}

\begin{abstract}
Background: COVID-19 disease has great effects on healthcare workers, especially nurses, and leads to psychological distress during care of COVID-19 patients. They regularly are in direct contact with patients from the time of admission to the discharge. This study aimed to explore the effect of COVID-19 health care provision on anxiety level among nurses in hospital using meta-analysis.

Subjects and Method: This was a systematic review and meta-analysis was conducted by PRISMA flow diagram. The articles were collected from PubMed, Google Scholar, and Science Direct databases. Keywords used "Anxiety" AND "Nurses" AND "COVID-19". Article search is carried out by considering the eligibility criteria, including population $=$ nurse, intervention $=$ COVID-19 health care service, comparison $=$ non COVID-19 health care service, and outcome $=$ anxiety. The inclusion criteria were full text, articles were published from year 2020 to 2021, cross-sectional studies, used English language, and reported adjusted Odds Ratio. Articles that met the criteria were analyzed by Revman $5 \cdot 3$.

Results: 6 studies from Iran, Jordan, Saudi Arabia, South Korea, Italia, were analyzed for meta-analysis. Nurse in COVID-19 health care unit had higher risk to anxiety 1.52 times $(\mathrm{aOR}=1.52 ; 95 \% \mathrm{CI}=1.16$ to $1.97 ; \mathrm{p}=0.002)$.

Conclusion: Nurse in COVID-19 health care unit has higher risk to anxiety than those who work in the general health care unit.
\end{abstract}

Keywords: anxiety, COVID-19, health care, nurse

\section{Correspondence:}

Andang Sudarmono. Masters Program in Public Health, Universitas Sebelas Maret. Jl. Ir. Sutami 36A, Surakarta 57126, Central Java. Email: andan_cf@yahoo.co.id. Mobile: 08156701457. 